cover inflation. Playing for safety, however, Riesenhuber plans also to encourage industry to finance more research. He considers that large projects can be better initiated and carried out by industry than by the cameral system of federal government. It remains to be seen how well he succeeds - and what the consequences would be for the government's own research establishments. Sarah Tooze

\section{Why the lag?}

Why has research in West Germany been a disappointment? Economically, West Germany has been if anything better off than its competitors. But West Germany has problems peculiar to itself, as follows:

- Length of education. Both school and university education take longer in West Germany than elsewhere, so that the average age for beginning a $\mathrm{PhD}$ is 27. The results are expense and loss of some of the most creative years.

- The $\mathrm{PhD}$ is finished at an age when tenured jobs and stability are more attractive than mobility, so grants for travel are undersubscribed.

- Too few untenured posts. Under German employment laws there must be a reason for ending a job. Despite loopholes and contrivances, mobility within the research community is limited.

- Legal responsibility of the Ordinarius $\left(\mathrm{C}_{4}\right)$ professors. By law, responsibility for finance and administration is usually vested only in the $\mathrm{C}_{4}$ professor. This creates a sharply pyramidal hierarchy which deprives other members of staff of responsibility.

- Research budgets of universities are contributed three quarters by the region (Land). This money goes automatically to the $\mathrm{C}_{4}$ professors, who have complete control and who are not subject to review of any kind. Federal money allotted by a normal grant system covers one quarter of university research spending and is the only money allocated subject to review.

- The 1976 university law laid down that all grant money, even when allocated to a specific person for a specific purpose, must be administered by the university. This has spawned a bureaucratic machine which leaves the grant-user trapped in a mesh of regulations and subject to interference. These procedures discourage industry from financing research in the universities.

- Inefficient administration. There is a lack of professionalism in the university administrations and administrators are rarely appointed within university departments to help research staffs and coordinate with the university.

- The numbers of students have soared, but despite overall increased spending, research money per head has fallen.

Polish universities

\title{
More signs of latent discontent
}

"Universities must not turn into an arena for political games", the Polish government newspaper Rzecspospolita warned as the new term opened on 1 October. Government and party officials were evidently worried that the reassembly of some 400,000 young people in the country's 87 universities and higher colleges could provide a focus for further confrontations - particularly in the atmosphere of heightened tension following the enactment of the new law on trade unions which dissolves all existing union structures (including the 11-million strong Solidarity). In the event, the students, whose own Independent Students' Association (NZS) was outlawed last January, reassembled peacefully, and the problem now facing the universities is not so much the threat of student political action but rather of inaction.

Calling for a "climate of normality" in the universities, the party daily Trybuna Ludu stated last week that "it will be difficult for the academic milieu to fulfil its task if it does not embark on a dialogue on such issues as the new law on higher education, improvement in upbringing and teaching methods, and the future of the student movement"'.

The President of the Council of State, Henryk Jablonski, reiterated this theme when conferring professorial diplomas in Warsaw on 6 October. Normal functioning of society will be impossible, he stressed, if citizens are "inactive", and students should therefore be trained to show "initiative, independent thinking and imagination". A conference of university lecturers from Lower Silesia and Opole went so far as to urge encouraging a "creative" approach by students to political and social studies (courses once more obligatory for all).

The students, however, seem reluctant to embark on dialogue with an academic establishment they no longer trust. Some 30 university rectors, elected under the previous democratic procedures have been replaced under martial law, and, under the political "verification" procedures, some 2 per cent of university staff have failed to meet the required criteria, while more than 5 per cent have been re-employed only conditionally, and $21 / 2$ per cent have had to take up non-teaching jobs within the universities.

"Internal emigration" - passive noncooperation with the political and social life of the country - became widespread among Polish intellectual and creative circles under martial law, and has been widely advocated in underground Solidarity literature. In what appears to be a last-ditch stand to "channel" the aspirations of the students, the authorities are now trying to establish a new students' organization, to replace both the banned
NZS and the party-linked Socialist Union of Polish Students (SZSP), a move that many SZSP activists themselves urge as a way to bring the mass of students back into the party fold.

Trade union law, which effectively put an end to hopes for a return to the liberalizations of $1980-81$ has already moved some Polish students to consider turning their internal emigration into an external one, and to try to continue their studies abroad. Some Western embassies in Warsaw, the British Embassy in particular, have already foreseen this possibility and are granting visas to students only if financial support is assured by a Western sponsor (see p.574). Such sponsors will not prove easy to find. In the United Kingdom, where a Polish Students' Appeal Fund was set up to help students stranded by the declaration of martial law, universities have been generous with free places, but funds for maintenance and such necessities as textbooks are, in the words of $\mathrm{Dr}$ Stanislaw Gomulka of the London School of Economics, "already over-extended".

Vera Rich

\section{Canada's research plans \\ Holding up}

\section{Washington}

Canada's ambitious five-year plan for a rapid growth of investment in research and development is in trouble - but it is surviving present economic difficulties more successfully than almost any other government initiative.

This mixed picture emerges from a report just issued by the Canadian National Research Council (NRC), the government's national laboratory. NRC's budget for the 1981-82 fiscal year fell short of the $\$ 304$ million it said it needed to carry out even the most restrictive of three alter-

OECD data on research and development expenditure

\begin{tabular}{lcc}
\hline Country & Year & $\begin{array}{c}\text { Expenditure as \% } \\
\text { of GDP }\end{array}$ \\
United States & 1980 & 2.49 \\
Switzerland & 1979 & 2.45 \\
Germany & 1979 & 2.27 \\
United Kingdom & 1979 & 2.20 \\
Japan & 1980 & 2.04 \\
Netherlands & 1978 & 1.97 \\
Sweden & 1977 & 1.90 \\
France & 1979 & 1.79 \\
Belgium & 1979 & 1.40 \\
Norway & 1979 & 1.37 \\
Yugoslavia & 1977 & 1.20 \\
Canada & 1981 & $1.18^{\star}$ \\
Finland & 1979 & 1.08 \\
Denmark & 1979 & 0.97 \\
Italy & 1979 & 0.82 \\
Turkey & 1978 & 0.59 \\
Portugal & 1978 & 0.32 \\
Greece & 1980 & 0.18 \\
\hline
\end{tabular}

*The OECD figures include social sciences and humanities research. The figures cited in the text $(1.07$ per cent current and 1.5 per cent goal) do not. 
natives in the 1980 five-year plan. That plan is aimed ultimately at doubling the production of technology-intensive industry by 1990 .

Even so, the \$296 million that NRC spent in 1981-82 was a 30 per cent increase over the previous year, allowing NRC to go ahead with several new programmes, including the Industrial Materials Research Institute in Boucherville, Quebec, an ice research project in Newfoundland and a small tokamak fusion research programme in cooperation with Hydro-Quebec.

NRC officials are worried, however, that the government will not be able to sustain the annual 30 per cent increases called for in the plan. Since budget items can be approved by the government throughout the fiscal year, the 1982-83 budget will not be known until the year is over, but officials are predicting that it will fall significantly short of the planned figure. The big worry is that what NRC calls "core support" is going to suffer the most. This is the reserve of expertise and backbone research facilities (analytical chemistry laboratories, for example) that NRC says must be built up if the government is to be able to address problems as they arise.
NRC officials say the tendency has been for immediate needs - such as the recent "fire-fighting" operation on the healtheffects of urea-formaldehyde foam insulation - to draw personnel and resources away from the core. This, they say, "jeopardizes the viability of NRC as Canada's national laboratory". It seems likely also to jeopardize the nation's effort to boost its overall research and development by 1985 from 1.07 per cent of gross national (GDP) to 1.5 per cent - and thus to bring it closer in line with the more industrialized countries of Western Europe.

\section{Bilingual planners disagree}

\section{Brussels}

Two separate plans to create an advanced electronics industry in Belgium have just been announced, one by the new Flemish regional government and the other by the central government's Minister for Science, Philip Maystadt. Although there are claims that the two plans complement one another, it seems likely that Belgian research and development policy will again become a source of conflict between the country's two communities.

Like the French plan and the European Commission's Esprit programme, the new initiatives spring from fears that European industry is in danger of missing the boat for the "Third Industrial Revolution" as the Flemish are calling it.

Since last December, Belgium's already complex political arena has been further complicated by the delegation of much of central government's power to two separate regional governments, one for Flanders and the other for Wallonia. The micro-electronics strategy presented by the president of the Flemish "government", Gaston Geens, is one of the first fruits of this constitutional change.

It will cost some BF 4,000 million ( $£ 44$ million) over the next four years. Unlike the French plan, it is strongly orientated towards stimulating private industry and differs in its emphasis on the production of customized chips. A large part of the funds will go towards establishing with Bell Telephone (a Belgian affiliate of ITT) a silicon foundry manufacturing customized microchips. The Belgian company is putting up half the cost of BF 2,800 million (£32.5 million) and the Flemish government the remainder.

The second element will be the major expansion of the research facilities at Leuven University, led by Professor Overstraeten, into a laboratory for advanced research into micro-electronics at a cost of some $\mathrm{BF} 1,500$ million. This will be complemented by a programme of grants to engineers already working in industry or finishing doctorates to improve their knowledge of the state of the art of very large-scale integrated chips and other fields. To help industry directly, there will be a consultancy centre where companies information technology industry.

can receive advice on how to computerize either their products or their production.

The Flemish micro-electronics programme has strong backing from the region's political parties, and industry has organized itself into pressure groups such as FLORA - Flemish companies interested in the development of the

The central government plan, still to be officially adopted, concentrates on creating a receptive environment for companies in the forefront of electronics. Above all, Maystadt proposes to use the public purchasing power of the state in the defence and telecommunications sectors to favour Belgian companies, particularly those seeking their first customer. This is

not strictly permitted under EEC or GATT rules, but Belgium awards more public works contracts to foreign companies than any other EEC country.

BF 200 million will also be set aside for subsidizing research and development work in companies involved in developing customized chips, in the belief that Belgium will never be able to compete with the French or Americans in producing standardized chips. A further BF 240 million will be spent on a study on the sociological impact of micro-electronics in an effort to calm the Walloon trade unions hostile to the changes their use will bring.

The central government's programme is estimated to cost BF 820 million a year but this figure may be revised in the light of efforts to cut the large government deficit.

Jasper Becker

\section{US medical profession \\ Fight against anti-trust laws}

\section{Washington}

The first of October may turn out to have been a decisive date for the medical profession in the United States, ending a shoot-out between the profession and the Federal Trade Commission (FTC), the government agency that seeks to monitor anti-competitive, anti-consumer practices in the medical profession (as well as others).

The issue, according to FTC's chairman, James C. Miller III, is whether the professions should be immune from the normal inquisitiveness of the agency empowered to protect consumers. "Admission to a profession should be a guarantee of competence, not a guarantee of immunity from the laws the rest of us must obey", Miller has said.

As long ago as December 1975, FTC issued a complaint against the American Medical Association (AMA), the profession's powerful umbrella organization, barring it from prohibiting advertising by doctors, among other things. Since then, AMA has fought the complaint in the courts. But when the US Supreme Court was deadlocked on the issue earlier this year, the FTC order automatically became effective on 1 October, the first day of fiscal year 1983 .
But AMA has not given up. Having failed in the courts, it seeks relief in Congress by amending FTC's authorizing legislation to prevent it from proceeding against the professions. The changes stood a good chance of being passed - reflecting AMA's considerable power in Washington - until Congress went into recess. AMA spokesmen still say they can change the law when Congress returns in November. But Congress's huge agenda, its lame-duck status and the Reagan Administration's support for FTC in this matter may combine to frustrate AMA's plans.

The fight has been long because several interlocking issues are involved: whether professionals can be the subject of antitrust action, whether FTC has the power to regulate the professions, whether AMA has reformed itself sufficiently in the past seven years to be considered now above reproach. To complicate matters, FTC has issued related orders against the American Dental Association (which agreed to be bound by the outcome of the AMA battle), the ophthalmologists, and several state and local medical societies. All these support AMA in its fight with FTC.

But the central issue is who should determine medical practice locally in the United States. FTC's position is that state and 